\title{
Materials Selection for Superheater Tubes in Municipal Solid Waste Incineration Plants
}

\author{
M. Morales, J.M. Chimenos, A.I. Fernández, and M. Segarra \\ (Submitted December 22, 2013; in revised form May 14, 2014; published online June 18, 2014)
}

\begin{abstract}
Corrosion reduces the lifetime of municipal solid waste incineration (MSWI) superheater tubes more than any other cause. It can be minimized by the careful selection of those materials that are most resistant to corrosion under operating conditions. Since thousands of different materials are already known and many more are developed every year, here the selection methodology developed by Prof. Ashby of the University of Cambridge was used to evaluate the performance of different materials to be used as MSWI superheater tubes. The proposed materials can operate at steam pressures and temperatures over 40 bars and $400{ }^{\circ} \mathrm{C}$, respectively. Two case studies are presented: one makes a balanced selection between mechanical properties and cost per thermal unit; and the other focuses on increasing tube lifetime. The balanced selection showed that AISI 410 martensitic stainless steel (wrought, hard tempered) is the best candidate with a good combination of corrosion resistance, a relatively low price $(0.83-0.92 € / \mathrm{kg})$ and a good thermal conductivity (23-27 W/m K). Meanwhile, Nitronic 50/XM-19 stainless steel is the most promising candidate for longterm selection, as it presents high corrosion resistance with a relatively low price $(4.86-5.14 € / \mathrm{kg})$ compared to Ni-alloys.
\end{abstract}

Keywords corrosion, heat exchanger tube, material selection, municipal solid waste incineration plant, Ni-alloys, stainless steel

\section{Introduction}

In the combustion boilers of municipal solid waste incineration (MSWI) also well-known as waste-to-energy (WtE) plants, corrosion problems occur. Numerous incidents of corrosion and erosion-corrosion of waterwall tubes, superheater tubes, and other pressure parts have been widely reported (Ref 1 ). In general terms, the main causes that lead to MSWI boiler tubes reaching the end of their useful life are well known. The flue gas environment is very aggressive, due to gas components, such as $\mathrm{HCl}, \mathrm{SO}_{2}, \mathrm{CO}, \mathrm{Cl}_{2}$, alkali metals, and heavy metals ( $\left.\mathrm{Zn}, \mathrm{Sn}, \ldots\right)$, which form chlorides with high vapor pressures (Ref 2$)$. The problems are often aggravated by variations in the mixed fuel including periods of a high chlorine load. Chlorine in MSW mainly originates in polyvinyl chloride (PVC) and sodium chloride $(\mathrm{NaCl})$ contained in the household rubbish that feeds the combustion chamber. The generated gases are deposited on tube walls by condensation or sublimation (Ref 3 ). Moreover, soft and sticky particles can be adhered to the heat transfer surfaces. These deposits contain salts such as chlorides, sulfates, oxides, and unburned particles, and thus result in low oxygen partial pressures near the metal surface. In addition, the melting and

M.Morales, J.M.Chimenos, A.I.Fernández, and M.Segarra, Centre DIOPMA, Departament de Ciència dels Materials i Enginyeria Metal-lúrgica, Universitat de Barcelona, C/Martí i Franquès 1, 08028 Barcelona, Spain. Contact e-mails:mmorales@ub.edu and mmoralescomas@yahoo.es. fluxing of low-melting-point compounds can accelerate corrosion, due to the formation of volatile metal chlorides, thus resulting in the formation of internal voids.

A lot of information on corrosion mechanisms and the effects of temperature and the formation of deposits can be found in the literature $(\operatorname{Ref} 4,5)$. It is generally accepted that the high level of chlorides in waste is the main cause of corrosion. High-temperature corrosion in $\mathrm{WtE}$ plants is caused by chlorine either in the form of $\mathrm{HCl}, \mathrm{Cl}_{2}$, or combined with $\mathrm{Na}, \mathrm{K}, \mathrm{Zn}, \mathrm{Pb}, \mathrm{Sn}$, and other elements (Ref 6). In particular, $\mathrm{HCl}$ gas, with a highly reducing atmosphere, and molten chlorides within the deposit are considered major factors. Sulfur compounds can be corrosive at high temperatures, thus their presence can make corrosion caused by chlorine a less important factor $(\operatorname{Ref} 7,8)$. The factors that most affect the corrosion of the boiler are the metal temperature, temperature difference between gas and metal, flue gas composition, formation of deposits, and reducing conditions; as well as the $\mathrm{SO}_{2} / \mathrm{HCl}$ ratio $(\mathrm{Ref} 9,10)$.

The boiler zones most sensitive to corrosion are the superheater tubes, as a result of the high temperatures and high pressures inside. Commonly, WtE plants are operated at steam pressures of 40 bars and a steam temperature of $400{ }^{\circ} \mathrm{C}$. However, further increases in boiler steam pressure and final temperature are desirable to increase the energy cycle efficiency; and some modern WtE plants can operate at higher steam parameters. For instance, new concepts allow the steam parameters to be increased to $440{ }^{\circ} \mathrm{C}$ and 130 bars (Ref 11). High-temperature corrosion is a thermally activated process; increased temperatures will therefore increase the potential for accelerated corrosion (Ref 12). Increased steam pressure will increase the maximum temperature within the superheater tubes, which will lead to an increase in the corrosion rate, even if the deposition of molten chlorides can be prevented by modifications to the corrosive environment, such as increasing turbulence (Ref 13). In such circumstances, better knowledge 
of the location in the boiler of the predominant corrosive environment could greatly assist effective alloy selection and use.

When WtE plants are operated at standard steam conditions (400 ${ }^{\circ} \mathrm{C}$ and 40 bars), $15 \mathrm{Mo} 3$ steel, which is a low-alloy steel with $0.3 \% \mathrm{Mo}$, is currently used. However, low-alloy steels cannot resist corrosion at steam parameters higher than standard, even if chlorine is present only at low concentrations (Ref 14, 15). Materials with adequate corrosion resistance to reducing combustion atmospheres that contain chlorine are highly alloyed, and thus expensive. The use of coatings is often justified because of difficulties associated with mechanical properties, workability, and the high price of high-alloy materials. Several methods for tube coating have been reported: co-extrusion (Ref 16), weld overlaying (Ref 17), diffusion coating (Ref 18), thermal spraying (Ref 19), and laser cladding (Ref 20).

Ni-based alloys are considered the most heat-resistant alloys. Corrosion via the formation of nickel chloride is more difficult than it is via Fe chlorides, and nickel chloride is less volatile than $\mathrm{Fe}$ chlorides are. The resistance of ferrous alloys increases as the Fe content decreases. In contrast, corrosion by $\mathrm{HCl}$ decreases with an increase in $\mathrm{Cr}$ and $\mathrm{Mo}$ contents. Several electrochemical studies performed using melted chloride salts have shown that additions of Mo can reduce the corrosion rate (Ref 21). In addition, the studies have shown that Ni additions are beneficial due to the formation of $\mathrm{NiO}$, and mixed $\mathrm{Ni}$ and $\mathrm{Fe}$ chromites, which are less soluble in melted chloride salts than chromium oxides are (Ref 22, 23). Ishitsuka and Nose (Ref 24) showed that the addition of $\mathrm{Mo}_{2} \mathrm{O}_{3}$ to a synthetic waste incineration deposit has the effect of partially reducing the corrosion rate of AISI304 stainless steel by decreasing the solubility of $\mathrm{Cr}_{2} \mathrm{O}_{3}$. Additions of $\mathrm{W}$ or $\mathrm{V}$ are expected to present the same effect. Therefore, alloying additions of $\mathrm{Ni}, \mathrm{Cr}, \mathrm{Mo}$, and $\mathrm{W}$ reduce the corrosion rate synergistically (Ref 21,25$)$.

Corrosion problems can be minimized by careful materials selection that are resistant to corrosion under operating conditions. Unfortunately, the choice of a boiler material is frequently the result of several compromises between, for example, corrosion resistance and mechanical strength or thermal conductivity. Moreover, the final selection may come down to a compromise between technical and economic factors. In $\mathrm{WtE}$ boilers, mechanical and thermal requirements, such as a high yield strength and thermal conductivity, are hard to accommodate while optimizing corrosion resistance and cost. Commonly, the most corrosion resistant materials are the most expensive.

Browsing or searching in handbooks and databases is useful for materials selection, especially when the selection process depends on only one or two properties. It seems easy to establish the proper relationships between key material properties. However, the difficulty lies in establishing the proper relationships/weightings/etc. between key factors and in finding all of the necessary data across classes of materials so that comparisons can be made. The aim of this work is to fill this gap for WtE plant superheater tubes. The Ashby approach was chosen as the method to achieve this goal. Various studies help address other issues of materials selection (Ref 26-30). This selection strategy was developed by Prof. Ashby and coworkers at the University of Cambridge, UK (Ref 31). It is based on the use of Granta's CES Selector software 2012 to construct charts of the properties of materials (Ref 32). In this work, suitable materials for use in WtE plant superheater tubes were determined for two case studies: long-term and balanced selections. First, the basis of the proposed approach with a short overview of methods for selecting materials, including the selection criteria and the objective function, is presented. Then, the results of the preliminary selection obtained via Granta's CES Selector software 2012 are discussed. From these data, the candidate alloys, which should fulfill the different constraints for the typical WtE plant superheater tubes, are presented for the two cases studied. Finally, the possible material candidates to be used for the superheater tubes are discussed, thus obtaining a ranking of the best candidates for each case.

\section{Methodology for Materials Selection}

In the context of superheater tubes design, the main goal of materials selection is to minimize cost maintaining the performance, as measured by key factors such as corrosion resistance. The materials selection is typically performed via intuitive and non-systematic approaches, which are based on the experience and inspiration of the engineers and researchers in a determined application. They often lead to a non-robust and subjective materials selection, especially when the studied system is complex and not well known. A systematic approach does not only lead to the selection of better quality materials than an intuitive one, but also more robust solutions are obtained under a wide variety of situations. In addition, the problems and decisions are quantitatively well-specified, the inputs are precisely defined and formulated, and it requires no more time than intuitive methods. In order to avoid the drawbacks of intuitive methods, systematic ones must be applied. Selection of the best material for a given application begins by studying the properties and the costs of candidate materials using materials databases; but their use for applications requiring multiple criteria, is complex.

In the present work, we used the CES Selector software, which is a practical and useful database of materials and processes (Ref $32,33)$. The starting point is a set of technical requirements for a component or subsystem. These are transformed into a set of limits or target values for the material properties or property combinations ("material indices"). It is then possible, given a comprehensive database of appropriate materials and their properties, to screen materials against these criteria, rank those that pass according to the target value of one or more indices, and finally draw in other associated documentation to make an optimally informed decision. The reasoning is made transparent by displaying the steps and the materials that pass and fail the screening steps in material property charts that present materials on axes of their properties or of the material indices. In other words, the problem statement firstly clarifies the main component of the function that defines the field and working environment. For this purpose, the model from which the attribute limits emerge is proposed, thus identifying the function constraints, objectives, and free variables, such as minimizing material cost, maximizing performance, and other objectives, as commented on below. Finally, the full menu is reduced by screening, using the objective function, to obtain at a relatively short list of viable candidates. For the present case study, the constraints to take into account are as follows:

(i) Yield strength: the superheater tubes should be designed to perform their function without yielding to the internal pressure. 
(ii) Thermal conductivity: heat has to flow through the material easily.

(iii) Corrosion resistance: the material should perform well in strongly corrosive environments.

(iv) Maximize service temperature: this is the highest temperature at which the material can be used continuously without oxidation, chemical change, or excessive distortion becoming a problem.

(v) Cost: it is important to choose the least expensive of the candidate materials.

(vi) Easy manufacturing: the material should be produce using the most common methods such as forging, casting, and/or welding.

(vii) Availability: the material should be available at the industrial scale.

Transforming these constraints into a mechanical design problem for a heat exchanger tube with a given tube radius operating at fixed pressure and temperature, by minimizing the material cost, $C_{\mathrm{m}}$, and maintaining good mechanical and thermal properties, the selection process yields the following equation (Ref 32):

$M=\frac{\sigma_{\mathrm{y}}^{2} \lambda}{C_{\mathrm{m}} \rho}$,

where $M$ is the material index to be maximized; $\sigma_{\mathrm{y}}$ yield strength $(\mathrm{MPa}) ; \lambda$, the thermal conductivity $(\mathrm{W} / \mathrm{m} \mathrm{K}) ; C_{\mathrm{m}}$, the material price $(€ / \mathrm{kg})$; and $\rho$, the material density $\left(\mathrm{kg} / \mathrm{m}^{3}\right)$. In other words, this index maximizes the heat flow per unit area while maximizing the strength and minimizing the cost of the tube. In order to obtain this index, pressure, and thermal difference, radius and wall thickness have been considered as constant. Materials with the highest value of $M$ are the best choice, provided that they also meet the other constraints stated above as selection criteria. Considering $M$ as a constant, taking $\operatorname{logs}$ in the materials index equation and rearranging, we get:

$\log \frac{\sigma_{\mathrm{y}}^{2}}{\rho}=\log \frac{C_{\mathrm{m}}}{\lambda}+\log M$.

This is the equation corresponding to a straight line of slope 1 on a plot of $\log \left(\sigma_{\mathrm{y}}^{2} / \rho\right)$ against $\log \left(C_{\mathrm{m}} / \lambda\right)$.

\section{Results and Discussion}

\subsection{Preliminary Materials Selection}

Materials were preliminarily selected with the help of the CES Selector software. Figure 1 shows, on the $x$-axis, the cost per thermal unit, $C_{\mathrm{m}} / \lambda$, and on the $y$-axis, the square strength per density unit, $\sigma_{\mathrm{y}}^{2} / \rho$, for different ferrous, nickel, and refractory alloys. These alloy families seem to be good candidates for superheater tube applications, as they present a good relationship between corrosion resistance in aggressive environments (in the presence of chloride and sulfide species, for example), mechanical resistance, weldability, cost, and availability on the market in tubular shape. Only those alloys with a maximum service temperature over $400{ }^{\circ} \mathrm{C}$, which is the standard service temperature in WtE plant superheaters, are plotted in the figure. A grid of lines corresponding to $M$ values from 1 to 10,000 is also shown.

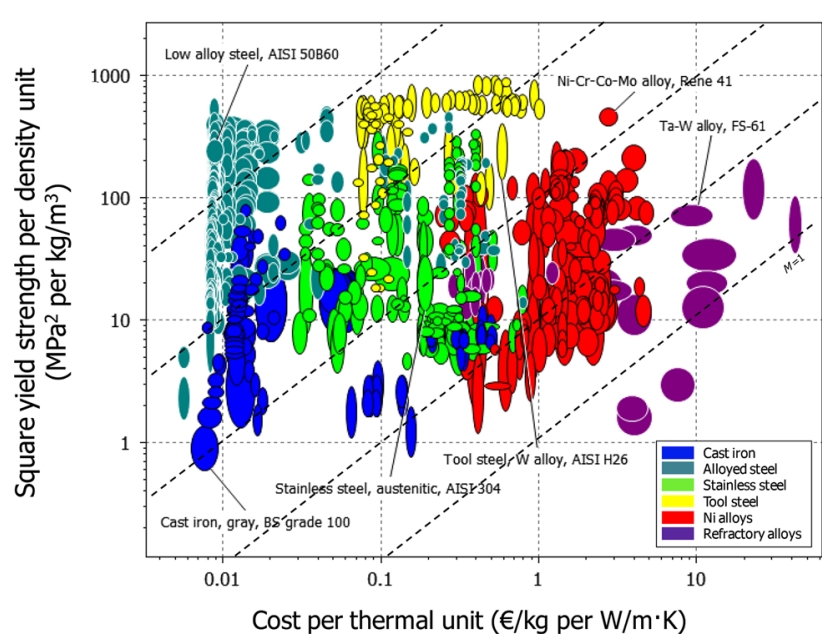

Fig. 1 Specific strength vs. cost per thermal unit for different ferrous, nickel, and refractory alloys, obtained with CES Selector

The best relation between yield strength squared per unit density and cost per thermal unit will be in the top left of the plot, which is the maximum value for $M$. All materials that lie on a line of constant $M$ perform equally well in terms of strength squared per density and cost per thermal unit, while also performing well in strongly corrosive environments. Those materials above the line perform better and those below less well. Cast irons (in blue), alloyed steels (in dark green), tool steels (in yellow), and stainless steels (in clear green) exhibit the highest values of $M$; that is, the best relationship between yield strength squared and cost per thermal unit or the minimum cost per unit of heat flow. Among alloyed steels, those with a low-alloy content present high $M$ values, such as those commonly used for heat-exchangers operating under standard steam conditions: $15 \mathrm{Mo} 3$ (DIN 17155) and St 35.8 (DIN 17175).

One of the constraints settled in the selection criteria is a minimum yield strength that allows an internal pressure of at least 40 bars, which is the typical steam pressure in $\mathrm{WtE}$ plants operating at $400{ }^{\circ} \mathrm{C}$ steam temperature. It can be estimated by the following equation (33):

$\sigma=\frac{p R}{t}$

where $\sigma$ is the minimum yield strength $(\mathrm{MPa})$ of the tube to avoid a failure, due to the internal pressure, $p(\mathrm{MPa})$; and $R$, outer radius $(\mathrm{m})$ and $t$, the wall thickness $(\mathrm{m})$ of the tube. If a tube with a diameter $(2 R)$ and wall thickness ratio of 5 is considered, which is typical for WtE plant superheater tubes, a yield strength of at least $20 \mathrm{MPa}$ is necessary. However, the yield strength determined at room temperature progressively decreases with increasing service temperature. In addition, wall thickness also reduces with increasing operating time, due to the evolution of corrosion. Corrosion can be also heterogeneously distributed, thus being located at specific zones due to overheating phenomenon; this is manifested by the presence of significant deposits that lead to a considerable reduction in wall thickness and excessive fire-side heat input (Ref 15). Taking into account that the yield strength range of $320-400 \mathrm{MPa}$ for the $15 \mathrm{Mo} 3$ steel typically used in WtE plant superheaters (Ref 15, 32), the minimum yield strength should be at least $400 \mathrm{MPa}$. Therefore, when applying this constraint to the previous selection, some materials are excluded from the plot. 


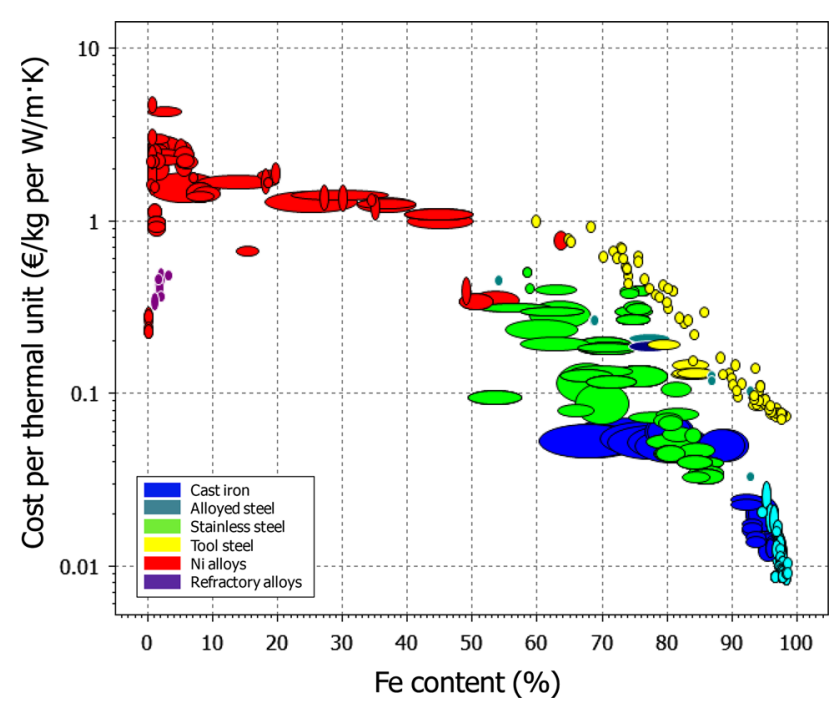

Fig. 2 Cost per thermal unit as a function of Fe content for different ferrous and non-ferrous alloys

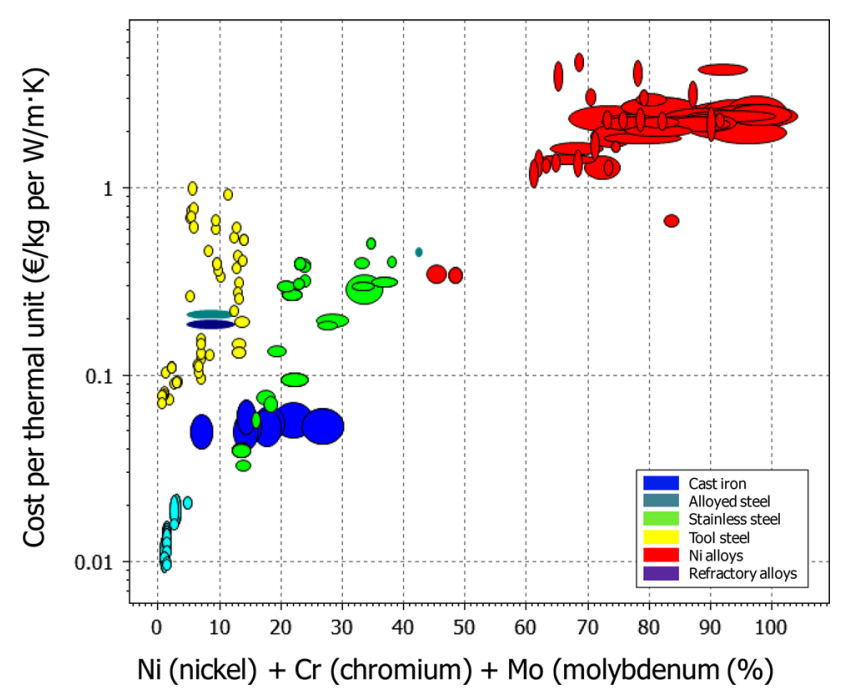

Fig. 3 Cost per thermal unit as a function of $(\mathrm{Ni}+\mathrm{Cr}+\mathrm{Mo})$ content for different ferrous and non-ferrous alloys containing any amount of the three elements
In contrast, the cost per thermal unit is related to the composition of the material and as observed in Fig. 2, it decreases with increasing Fe content; however, it also increases with increasing content of alloying elements such as $\mathrm{Ni}, \mathrm{Cr}$, and Mo (Fig. 3). Cast irons are considered brittle, with a relatively low thermal and mechanical shock resistance, and so in accordance with these criteria, cast irons should not be selected for superheater tubes.

Other design constraints on the selected materials are the corrosion resistance and the workability. Most metal alloys present a high workability (Ref 34 ); so this property will only be studied for the materials finally selected, as it does not constitute a significant constraint in the selection process. In contrast, corrosion resistance is not easily quantified, and therefore, it is difficult to include in the materials selection. The properties of materials depend strongly on their composition, and in the case of the corrosion resistance of alloys, it can be modulated by varying the alloy composition. Some experimental studies that establish relationships between alloy composition and corrosion resistance by pitting can be found in the literature ( $\operatorname{Ref} 35-40)$. A parameter that is an estimate of pitting resistance is the pitting resistance equivalent number (PREN). There are several PREN equations for each alloy family (Table 1). Some of the most common expressions for some stainless, duplex, and superaustenitic steels have been reported (Ref 35-37). Other equations show a common formula used to compare the pitting resistance in both stainless steels and nickel-based alloys (Ref 37, 38). According to those equations, the pitting resistance can be increased respect to the value the same content of $\mathrm{Cr}$ would yield, between 1.5- and 30fold, depending on the element added. It is important to comment that the $\mathrm{N}$ addition is limited in these alloys, and the $\mathrm{N}$ solubility can be increased by the addition of $\mathrm{Mn}$. In other work, the PRENs are only specified for Ni-alloys depending on the experimental conditions (Ref 39, 40). As a general tendency, it can be considered that an increase in $\mathrm{Ni}, \mathrm{Cr}$, and Mo content leads to an increase of the corrosion resistance for ferrous alloys. The oxidation products of these elements form protective layers, which restrict the oxidation process at the metal surface. Nevertheless, ferritic chromium steels containing high percentages of an alloying element become brittle in the range $300-600{ }^{\circ} \mathrm{C}$, whereas this effect is lower for austenitic steels and not significant for steels with an $\mathrm{Ni}$ content greater than $30 \%$. However, as can be seen in Fig. 3, the cost per thermal unit also increases.

Table 1 Factors of pitting resistance equivalent number (PREN) equations for different alloy families

\begin{tabular}{|c|c|c|c|c|c|c|c|c|}
\hline \multirow[b]{2}{*}{ Alloy group } & \multicolumn{7}{|c|}{ Factors of PREN equations for each element } & \multirow[b]{2}{*}{ References } \\
\hline & $A_{\mathbf{C r}}$ & $\boldsymbol{B}_{\mathbf{M o}}$ & $C_{\mathrm{Nb}}$ & $D_{\mathbf{W}}$ & $E_{\mathbf{N}}$ & $\boldsymbol{F}_{\mathbf{C u}}$ & $G_{\mathrm{Ni}}$ & \\
\hline \multirow[t]{2}{*}{ Stainless, duplex, and superaustenitic steels } & 1.0 & 3.3 & $\ldots$ & 16 & $\ldots$ & $\ldots$ & $\ldots$ & {$[35,36]$} \\
\hline & 1.0 & 1.5 & 1.0 & 30 & $\ldots$ & $\ldots$ & $\ldots$ & {$[36,37]$} \\
\hline \multirow[t]{2}{*}{ Stainless steels and Ni-based alloys } & 1.0 & 1.5 & 1.5 & 30 & 1.5 & $\cdots$ & $\ldots$ & {$[37,38]$} \\
\hline & 1.0 & 1.5 & 1.5 & $\ldots$ & $\ldots$ & 0.5 & $\ldots$ & [39] \\
\hline \multirow[t]{2}{*}{ Ni-based alloys } & 1.0 & 2.0 & 1.0 & $\ldots$ & $\ldots$ & $\ldots$ & $\ldots$ & [40](a) \\
\hline & 2.0 & 2.0 & 2.0 & $\ldots$ & $\ldots$ & $\ldots$ & 1.0 & [40](b) \\
\hline
\end{tabular}

PREN $=A_{\mathrm{Cr}} \cdot(\% \mathrm{Cr})+B_{\mathrm{Mo}} \cdot(\% \mathrm{Mo})+C_{\mathrm{Nb}} \cdot(\% \mathrm{Nb})+D_{\mathrm{W}} \cdot(\% \mathrm{~W})+E_{\mathrm{N}} \cdot(\% \mathrm{~N})+F_{\mathrm{Cu}} \cdot(\% \mathrm{Cu})+G_{\mathrm{Ni}} \cdot(\% \mathrm{Ni})$. For Ni-alloys exposed at (a) $550{ }^{\circ} \mathrm{C}$, and $(\mathrm{b})$ $650{ }^{\circ} \mathrm{C}$ for $336 \mathrm{~h}$ in $\mathrm{N}_{2}-10 \% \mathrm{O}_{2}-\mathrm{CO}_{2}-20 \% \mathrm{H}_{2} \mathrm{O}-1500 \mathrm{ppm} \mathrm{HCl}-300 \mathrm{ppm} \mathrm{SO}_{2}$ 
Even though numerical data related to PRENs for all ferrous and non-ferrous alloys cannot be included in the CES Selector software, the qualitative durability of the alloys in strong acid environments may be represented as shown in Fig. 4. All the alloys plotted in the figure have a yield strength higher than $400 \mathrm{MPa}$, a maximum service temperature over $400{ }^{\circ} \mathrm{C}$, and an acceptable or excellent durability in strong acid media. From these criteria, those alloys with the lowest cost per thermal unit are austenitic, martensitic, ferritic, and duplex stainless steels. The best alternatives to stainless steels or ferrous alloys are the Ni-based alloys, although their cost per thermal unit is from 10 to 100 times higher. Table 2 summarizes some properties of the main ferrous and non-ferrous alloy families. As can be deduced from the data in the table, materials presenting the highest ratio between strength squared per density unit and cost per thermal unit (that is the highest $M$ value) are not those with the best durability in strong acidic media. Thus, two case studies can be now formulated: a balanced selection to maximize the material index with a moderate durability in strong acid media, which translates to a shorter lifetime; and a long-term selection, where the corrosion resistance (or a longer lifetime) is preferred over a lower cost of the tubes.

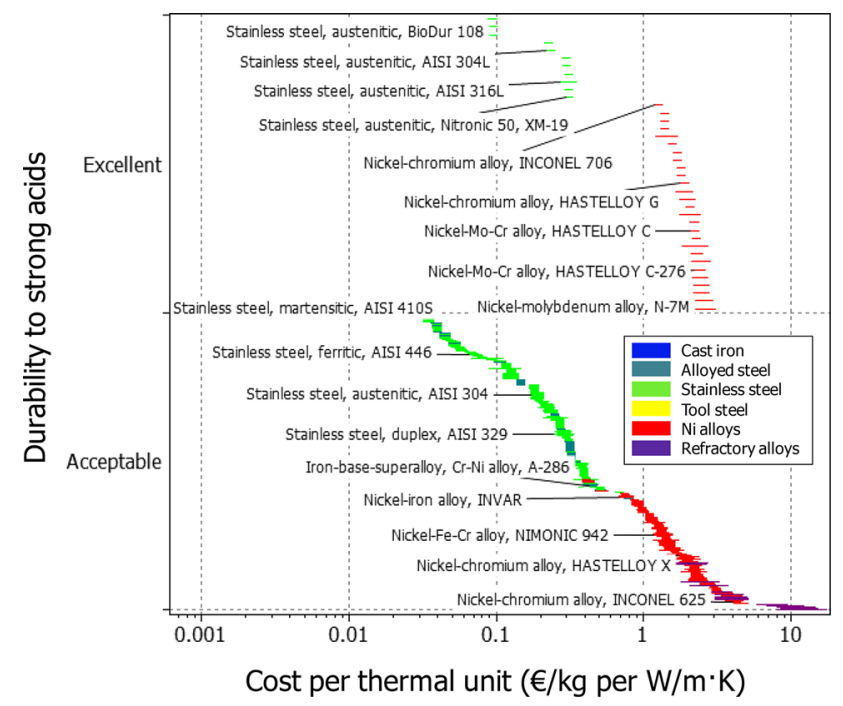

Fig. 4 Relationship between the corrosion resistance in strong acid environment and the cost per thermal unit for different ferrous and non-ferrous alloy families

\subsection{Balanced Selection Case Study}

To select a material with a balanced relation between cost and performance, the following limits have been applied as constraints that must be strictly satisfied:

(i) Yield strength $\geq 400 \mathrm{MPa}$.

(ii) Maximum service temperature $\geq 400{ }^{\circ} \mathrm{C}$.

(iii) Durability in strong acid media: acceptable or excellent.

Figure 5 shows those materials that fulfill the requirements, with a cost per thermal unit lower than 1 . Table 3 summarizes the properties of the elements plotted in Fig. 5 with the highest value for the material index. In this table, the materials are ranked according to their materials' indices using Eq 1. Martensitic and ferritic stainless steels are the best candidates, as they achieve a good compromise between mechanical properties and their cost per thermal unit, with good behavior in strong acid media. The main advantages of these steels are their high mechanical and corrosion resistance compared to the $15 \mathrm{Mo} 3$ steel (220-275 MPa, 37-49 W/m K) and St 35.8 steels (215-235 MPa, 35-50 W/m K) typically used (Ref 41). So, their yield strengths are relatively high, which is an important parameter when the material has to work at high pressures, and they present a thermal conductivity between 15 and $31 \mathrm{~W} / \mathrm{m} \mathrm{K}$,

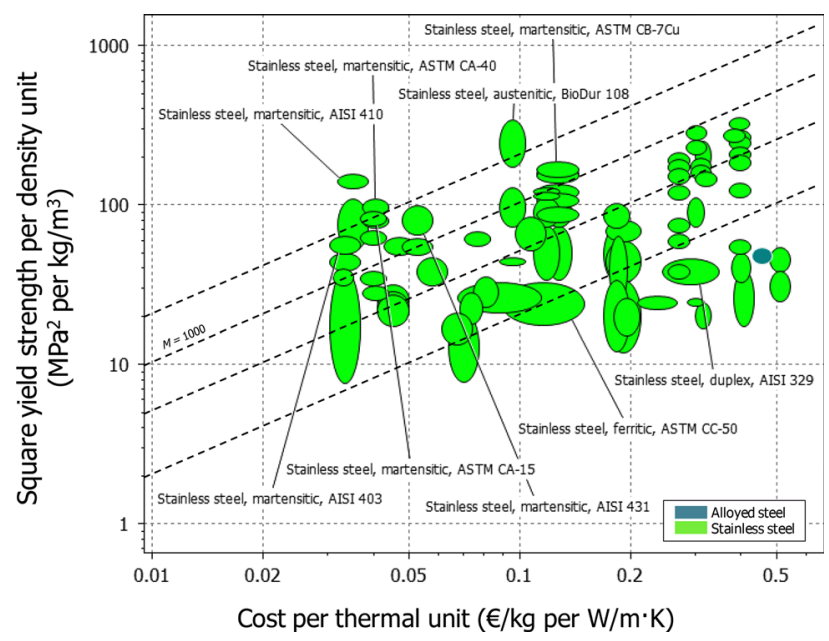

Fig. 5 Specific strength vs. cost per thermal unit for different alloys, obtained with CES Selector, with the balanced selection criteria

Table 2 Mechanical and thermal properties, corrosion resistance, and cost for different Fe- and Ni-alloys ranked by material index

\begin{tabular}{|c|c|c|c|c|c|c|}
\hline Alloy group & $\begin{array}{l}\text { Square yield strength } \\
\text { per density unit, } \\
\mathrm{MPa}^{2} \text { per } \mathrm{kg} / \mathrm{m}^{3}\end{array}$ & Cost, $€ / \mathbf{k g}$ & $\begin{array}{c}\text { Thermal } \\
\text { conductivity, } \\
\text { W/m K }\end{array}$ & $\begin{array}{c}\text { Cost per thermal } \\
\text { unit, } € / \text { kg per } \\
\text { W/m kg }\end{array}$ & $\begin{array}{l}\text { Material } \\
\text { index }\end{array}$ & $\begin{array}{l}\text { Durability to } \\
\text { strong acids }\end{array}$ \\
\hline Low-alloy steels & $1-500$ & $0.3-1.1$ & $35-60$ & $0.008-0.3$ & $800-32,000$ & Unacceptable \\
\hline Intermediate alloy steels & $200-350$ & $0.9-5$ & $20-30$ & $0.05-0.2$ & $1600-8900$ & Unacceptable \\
\hline Refractory alloys & $1-210$ & $32-1610$ & $30-142$ & $0.3-46$ & $1-7800$ & Acceptable or excellent \\
\hline Tool steels & $15-1000$ & $3-20$ & $20-50$ & $0.06-1$ & $200-7300$ & Unacceptable \\
\hline Cast irons & $0.5-100$ & $0.4-1.5$ & $18-40$ & $0.005-0.02$ & $200-5600$ & Unacceptable \\
\hline Martensitic stainless steels & $5-350$ & $1-6$ & $15-30$ & $0.1-0.6$ & $140-4100$ & Acceptable \\
\hline Austenitic stainless steels & $10-350$ & $1-9$ & $15-20$ & $0.1-1$ & $60-2600$ & Acceptable or excellent \\
\hline Ferritic stainless steels & $5-35$ & $2-3$ & $15-30$ & $0.05-1$ & $200-500$ & Acceptable \\
\hline Ni-based alloys & $1-600$ & $10-55$ & $8-20$ & $0.2-6$ & $4-300$ & Acceptable or excellent \\
\hline Duplex stainless steels & $20-55$ & $4-9$ & $15-20$ & $0.2-0.6$ & $60-130$ & Acceptable \\
\hline
\end{tabular}


Table 3 Mechanical and thermal properties, corrosion resistance, cost, and material index for materials that best fulfill the balanced selection criteria

\begin{tabular}{|c|c|c|c|c|c|c|}
\hline Alloy name & $\begin{array}{c}\text { Yield } \\
\text { strength, } \\
\text { MPa }\end{array}$ & Cost, $€ / \mathrm{kg}$ & $\begin{array}{c}\text { Thermal } \\
\text { conductivity, } \\
\text { W/m K }\end{array}$ & $\begin{array}{c}\text { Material } \\
\text { index }\end{array}$ & $\begin{array}{c}\text { Max. service } \\
\text { temperature, }{ }^{\circ} \mathrm{C}\end{array}$ & $\begin{array}{l}\text { Durability to } \\
\text { strong acids }\end{array}$ \\
\hline $\begin{array}{l}\text { AISI } 410 \text { martensitic stainless steel, } \\
\text { wrought, hard temper }\end{array}$ & $1000-1100$ & $0.83-0.92$ & $23-27$ & 4050 & $700-800$ & Acceptable \\
\hline $\begin{array}{l}\text { BioDur } 108 \text { austenitic stainless steel, } \\
\text { wrought, } 30-40 \% \text { cold worked }\end{array}$ & $1160-1620$ & $1.45-1.60$ & $15-17$ & 2580 & $750-790$ & Excellent \\
\hline $\begin{array}{l}\text { ASTM CA- } 40 \text { martensitic stainless } \\
\text { steel, cast, tempered at } 595{ }^{\circ} \mathrm{C}\end{array}$ & $815-910$ & $0.94-1.03$ & $23-26$ & 2420 & $535-585$ & Acceptable \\
\hline $\begin{array}{l}\text { AISI } 410 \text { martensitic stainless steel, } \\
\text { wrought, intermediate temper }\end{array}$ & $634-917$ & $0.83-0.92$ & $23-27$ & 2140 & $700-800$ & Acceptable \\
\hline $\begin{array}{l}\text { ASTM CA- } 15 \text { martensitic stainless } \\
\text { steel, cast, tempered at } 595^{\circ} \mathrm{C}\end{array}$ & $755-835$ & $0.92-1.02$ & $23-26$ & 2090 & $535-585$ & Acceptable \\
\hline $\begin{array}{l}\text { ASTM CA- } 40 \text { martensitic stainless } \\
\text { steel, cast, tempered at } 650{ }^{\circ} \mathrm{C}\end{array}$ & $740-820$ & $0.94-1.03$ & $23-26$ & 1980 & $590-640$ & Acceptable \\
\hline $\begin{array}{l}\text { AISI } 403 \text { martensitic stainless } \\
\text { steel, wrought, hard temper }\end{array}$ & $550-620$ & $0.79-0.87$ & $23-27$ & 1330 & $700-750$ & Acceptable \\
\hline $\begin{array}{l}\text { ASTM CA- } 15 \text { martensitic stainless } \\
\text { steel, cast, tempered at } 650{ }^{\circ} \mathrm{C}\end{array}$ & $655-725$ & $0.92-1.02$ & $23-26$ & 1570 & $590-640$ & Acceptable \\
\hline $\begin{array}{l}\text { AISI } 431 \text { stainless steel, martensitic, } \\
\text { wrought, tempered at } 593{ }^{\circ} \mathrm{C}\end{array}$ & $715-875$ & $0.95-1.03$ & $23-27$ & 1530 & $530-580$ & Acceptable \\
\hline $\begin{array}{l}\text { AISI } 403 \text { stainless steel martensitic, } \\
\text { wrought, intermediate temper }\end{array}$ & $550-620$ & $0.79-0.87$ & $23-27$ & 1330 & $550-620$ & Acceptable \\
\hline
\end{tabular}

Table 4 Mechanical and thermal properties, corrosion resistance, cost and material index for materials that best fulfill the long-term selection criteria

\begin{tabular}{|c|c|c|c|c|c|c|}
\hline Alloy name & $\begin{array}{c}\text { Yield } \\
\text { strength } \\
\text { (MPa) }\end{array}$ & Cost $(€ / \mathbf{k g})$ & $\begin{array}{c}\text { Thermal } \\
\text { conductivity } \\
(\mathrm{W} / \mathrm{m} \mathrm{K})\end{array}$ & $\begin{array}{l}\text { Material } \\
\text { index }\end{array}$ & $\begin{array}{c}\text { Max. service } \\
\text { temperature }\left({ }^{\circ} \mathrm{C}\right)\end{array}$ & $\begin{array}{l}\text { Durability to } \\
\text { strong acids }\end{array}$ \\
\hline $\begin{array}{l}\text { BioDur } 108 \text { austenitic stainless steel, } \\
\text { wrought, } 30-40 \% \text { cold worked }\end{array}$ & $1160-1620$ & $1.45-1.60$ & $15-17$ & 2580 & $750-790$ & Excellent \\
\hline $\begin{array}{l}\text { BioDur } 108 \text { austenitic stainless steel, } \\
\text { wrought, } 10-20 \% \text { cold worked }\end{array}$ & $752-986$ & $1.45-1.60$ & $15-17$ & 1020 & $750-790$ & Excellent \\
\hline $\begin{array}{l}\text { Nitronic 50, XM-19 austenitic stainless steel, } \\
\text { wrought, cold drawn, wire } \\
\text { (nitrogen strengthened) }\end{array}$ & $1140-1400$ & $4.86-5.14$ & $15-16$ & 648 & $750-790$ & Excellent \\
\hline $\begin{array}{l}\text { BioDur } 108 \text { austenitic stainless steel, } \\
\text { wrought, annealed }\end{array}$ & $580-592$ & $1.45-1.60$ & $15-17$ & 472 & $750-790$ & Excellent \\
\hline $\begin{array}{l}\text { ASTM F1586 austenitic stainless steel, wrought, } \\
\text { medium hard, nitrogen strengthened }\end{array}$ & $760-934$ & $4.01-4.41$ & 14 & 300 & $750-790$ & Excellent \\
\hline $\begin{array}{l}\text { INCONEL } 706 \text { nickel-chromium alloy, } \\
\text { wrought, solution treated }\end{array}$ & 896-1000 & $14.9-16.3$ & $12-13$ & 87.4 & $632-705$ & Excellent \\
\hline $\begin{array}{l}\text { ASTM F1586 austenitic stainless steel, } \\
\text { wrought, annealed, nitrogen strengthened }\end{array}$ & $432-452$ & $4.01-4.41$ & 14 & 82.5 & $750-790$ & Excellent \\
\hline $\begin{array}{l}\text { INCONEL } 718 \text { nickel-chromium alloy, } \\
\text { wrought, solution treated, and aged }\end{array}$ & $1000-1100$ & $19.4-21.3$ & $12-13$ & 80 & $632-705$ & Excellent \\
\hline $\begin{array}{l}\text { Nitronic 50, XM-19 austenitic stainless steel, } \\
\text { wrought, annealed (nitrogen strengthened) }\end{array}$ & $363-434$ & $4.68-5.14$ & $15-16$ & 64.2 & $750-790$ & Excellent \\
\hline $\begin{array}{l}\text { INCONEL } 718 \text { nickel-chromium alloy, } \\
\text { wrought, solution treated }\end{array}$ & $724-800$ & $19.4-21.3$ & $12-13$ & 41.9 & $632-705$ & Excellent \\
\hline
\end{tabular}

which ensures a good exchange of heat at a low cost. Among these materials, AISI 410 martensitic stainless steel (wrought, hard tempered) performs the best from among all the candidates. This is a basic martensitic stainless steel that retains its mechanical properties after heat treatment and has a good corrosion resistance (Ref 42). The main applications of this steel are steam and gas turbine blades and buckets. The next best material is BioDur 108 austenitic stainless steel (wrought,
$30-40 \%$ cold worked), which is a nickel-free alloy designed for medical applications. BioDur 108 exhibits both significantly higher corrosion resistance at room temperature and significantly higher strength than any of the common nickelcontaining stainless alloys, in both the annealed and cold worked conditions, which is strongly related to levels of chromium, molybdenum, and nitrogen (Ref 43). However, it presents a low thermal conductivity and its corrosion resistance 


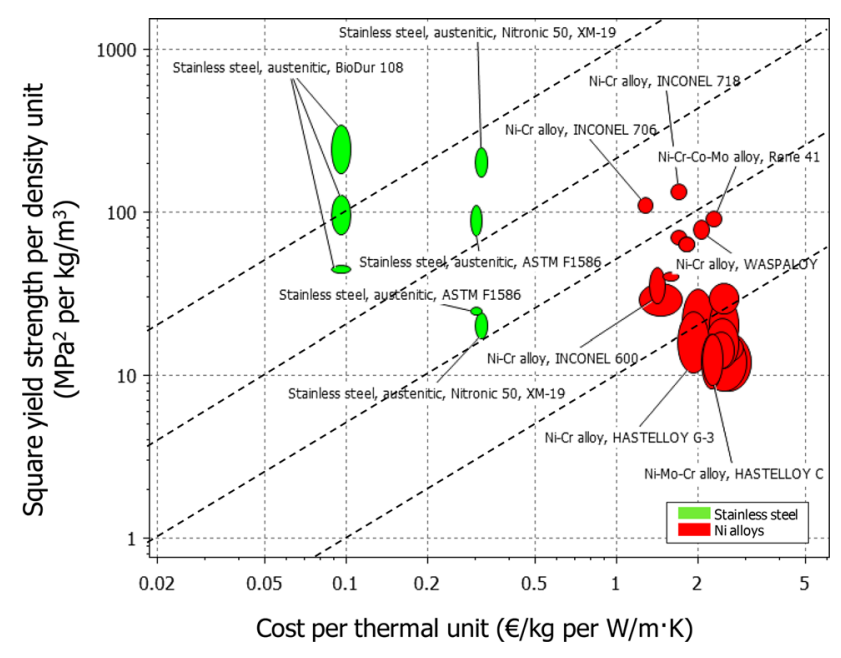

Fig. 6 Specific strength vs. cost per thermal unit for different alloys, obtained with CES Selector, with the long-term selection criteria

has only been tested at room temperature. The third material is ASTM CA40, which is an iron-chromium alloy with good corrosion resistance used in steam turbine parts, among other applications.

\subsection{Long-Term Selection Case Study}

When the most important criterion for the selection of materials is the lifetime of the superheater tubes, then the material must have an excellent durability in strong acid media, while cost and thermal conditions are not considered so closely. Therefore, the constraints become:

(i) Yield strength $\geq 400 \mathrm{MPa}$.

(ii) Maximum service temperature $\geq 400{ }^{\circ} \mathrm{C}$.

(iii) Durability in strong acid media: excellent.

Table 4 summarizes the main mechanical and thermal properties involved in the selection process for the best candidates that fulfill all the long-term selection criteria. As shown in Fig. 6 and Table 4, Ni-based alloys and some of specific austenitic stainless steels are the best candidates for longterm selection, due to their excellent durability in strong acid media. The austenitic stainless steels, such as BioDur 108, Nitronic 50 (XM-19), and ASTM F1586, present the highest performance indices. Ni-alloys present lower thermal conductivities than stainless steels and their prices are also higher, this makes their costs per thermal unit higher than for stainless steels. However, their maximum service temperatures are higher, thus indicating that mechanical properties would be maintained up to higher temperatures, thereby extending their lifetime. Among the Ni-based alloys selected, INCONEL 706 presents the highest material index, which is achieved with a thermal conductivity of $12-13 \mathrm{~W} / \mathrm{m} \mathrm{K}$ and a relatively acceptable price $(14.9-16.3 € / \mathrm{kg}$ ) compared to other Ni-alloys (Ref 44, 45; Table 4).

Before selecting the material with the highest performance, it is necessary to browse the literature in order to find possible uses of this material, details of its properties, availability and pricing, as well as commercialized shapes. BioDur 108 is essentially a nickel-free stainless steel alloy designed for medical implants. It offers excellent resistance to pitting and crevice corrosion at room temperature (Ref 43). Nitronic 50 (XM-19) is a nitrogen-strengthened austenitic stainless steel that provides very good resistance to corrosion, an excellent combination of strength, ductility, and toughness, even at cryogenic temperatures (Ref 46). It has been used in applications such as pumps and fittings for chemical equipment, fasteners, cables, chains, screens, and marine hardware. It is available in the following forms: seamless pipe, welded pipe, seamless tube, welded tube, bar, wire, sheet, plate, forgings, pipe fittings, and flanges. ASTM F1586 (BioDur 734 alloy) is another wrought nitrogen-strengthened stainless steel for surgical implants. Both stainless steels are used in medical applications, so their corrosion resistances have been tested only at room temperature. Most of these materials have a decrease in their corrosion resistance as well as in their mechanical properties as the temperature increases. In this case, as no information about the behavior of these nickel-free stainless steels can be found in the literature, we must reject them and keep Nitronic 50 (XM-19) stainless steel as the best selection for the described purpose.

\section{Conclusions}

The proposed methodology allows us to evaluate the performance of different materials to be used as MSWI superheater tubes. The proposed materials can operate at steam pressures and temperatures higher than 40 bars and $400{ }^{\circ} \mathrm{C}$, respectively. Two case studies are presented: the first taking into account a balanced selection between mechanical properties and cost per thermal unit; the other focusing on increased lifetime.

The use of a material index leads to the selection of materials that perform a certain function better. Nevertheless, it is important to look at the data in the literature before taking a decision. Nickel-free stainless steel alloys are a case in point; they are used as medical implants and present high corrosion resistance, but have not been tested at high temperatures.

The balanced selection shows that AISI 410 martensitic stainless steel (wrought, hard tempered) would be the best candidate with a good combination of corrosion resistance, a relatively low price $(0.83-0.92 € / \mathrm{kg})$ and good thermal conductivity (23-27 W/m K). However, Nitronic 50/XM-19 stainless steel is the most promising candidate for a long-term selection, as it presents high corrosion resistance at a relatively low price (4.86-5.14 €/ $\mathrm{kg}$ ) compared to Ni-alloys.

\section{Acknowledgments}

The authors thank R. Nadal (General Manager of SIRUSA) and the SIRUSA Incineration Plant for useful discussions and for financing this work, and Mrs. Toffa Evans of the Language Services of the University of Barcelona for language revision. This study was also financed by the Spanish MICINN under the ENE2011-28269C03-02 Project, and XaRMAE (Xarxa de Referència en Materials Avançats per l'Energia, Generalitat de Catalunya).

\section{References}

1. I.G. Wright and H.H. Krause, Assessment of Factors Affecting Boiler Tube Lifetime in Waste-Fired Steam Generators: New Opportunities for Research and Technology Development, ASME, New York, 1994, $\mathrm{p}$ $1-112$ 
2. H.J. Grabke, E. Reese, and M. Spiegel, The Effects of Chlorides, Hydrogen Chloride, and Sulfur Dioxide in the Oxidation of Steels Below Deposits, Corros. Sci., 1995, 37, p 1023-1043

3. Y.S. Lia, M. Spiegel, and S. Shimada, Corrosion Behaviour of Various Model Alloys with NaCl-KCl Coating, Mater. Chem. Phys., 2005, 93, p 217-223

4. A. Zahs, M. Spiegel, and H.J. Grabke, Chloridation and Oxidation of Iron, Chromium, Nickel and Their Alloys in Chloridizing and Oxidizing Atmospheres at $400-700^{\circ} \mathrm{C}$, Corros. Sci., 2000, 42, p 1093-1122

5. Y. Kawahara, High-Temperature Corrosion Mechanisms of Fe-Based Alloys in $\mathrm{NaCl}$ Containing Atmospheres, Corros. Sci., 2002, 44, p 223-245

6. M. Morales, J.M. Chimenos, F. Espiell, and M. Segarra, The Effect of Temperature on Mechanical Properties of Oxide Scales Formed on a Carbon Steel in a Simulated Municipal Solid Waste Incineration Environment, Surf. Coat. Technol., 2014, 238, p 51-57

7. J. Stringer, Performance Limitations in Electric Power Generating Systems Imposed by High Temperature Corrosion, High Temp. Technol., 1985, 3, p 119-134

8. D.B. Meadowcroft, Some Critical Industrial Requirements and Experience Related to High-Temperature Corrosion, Mater. Sci. Eng. A, 1989, 121, p 669-675

9. H.H. Krause, Effects of Flue-Gas Temperature and Composition on Corrosion from Refuse Firing, Corrosion NACE International, 1991, 242, p 6-10

10. Y. Kawahara, Recent Trends in Development and Application of High-temperature Corrosion-Resistant Materials and Coatings in High Efficiency Waste Incineration Boiler, MTERE2 41, 2002, p 190-194

11. J. Wandschneider, U. Seiler, G. Hölter, and T. Wilmann, Increase of the Electrical Energy Efficiency to $30 \%$ Due to a High Performance Boiler-Example of HR-AVI-Amsterdam (Steigerung des elektrischen Wirkungsgrades bis 30\% durch eine Hochleistungskesselanlage am Beispiel der HR-AVI-Amsterdam), Optimization in Thermal Waste Treatment (Optimierung der Abfallverbrennung) 1, K.J. ThoméKozmiensky and M. Beckmann, Ed., Neuruppin. TK Verland Karl Thomé-Kozmiensky, Neuruppin, 2005, p 1-15

12. Y. Kawahara, M. Nakamura, H. Tsuboi, and K. Yukawa, High Efficiency Waste-to-Energy Plants, Corrosion, 1998, 54, p 576-589

13. P. Rademakers, W. Hesseling, and J. van de Wetering, Review on Corrosion in Waste Incinerators, and Possible Effects of bromine, TNO Industrial Technology, 2002, p 18-25

14. W.T. Bakker, The Effect of Chlorine on Mixed Oxidant Corrosion of Stainless Steels, Mater. High Temp., 1997, 14, p 197-205

15. M. Noguchi, H. Yakuwa, M. Miyasaka, M. Yokono, A. Matsumoto, and K. Miyoshi, Experience of Superheater Tubes in Municipal Waste Incineration Plant, Mater. Corros., 2000, 51, p 774-785

16. E.P. Latham, D.B. Meadowcroft, and L. Pinder, Coextrusion Cladding for Oxidation Protection, Mater. Sci. Technol., 1989, 5, p 813-815

17. U. Brill and G.K. Grossmann, Corrosion Behavior of Weld Overlays of the New Alloy 50, Corrosion, 2001, 170, p 11-16

18. J. Stringer, Coatings in the Electricity Supply Industry: Past, Present, and Opportunities for the Future, Surf. Coat. Technol., 1998, 1, p 108-109

19. S.T. Bluni and A.R. Marder, Effects of Thermal Spray Coating Composition and Microstructure on Coating Response and Substrate Protection at High Temperatures, Corrosion, 1996, 52, p 213-218

20. M.S. Brennan and R.C. Gassmann, Laser Cladding of Nickel and Iron Base Alloys on Boiler Waterwall Panels and Tubes, Corrosion, 2000, 235, p 26-31

21. J.R. Hayes, J. Gray, A.W. Szmodis, and C.A. Orme, Influence of Chromium and Molybdenum on the Corrosion of Nickel Based Alloys, J. Electrochem. Soc., 2005, 62, p 491-494

22. K. Nakagawa, Y. Matsunaga, and K. Yukawa, An Electrochemical Investigation of Corrosion of Superheater Tube in Waste Incineration Environment, Corrosion, NACE International, 1997, p 1-10
23. H. Lefaix-Jeuland, L. Marchetti, S. Perrin, M. Pijolat, M. Sennour, and R. Molins, Oxidation Kinetics and Mechanisms of Ni-Alloys in Pressurised Water Reactor Conditions: Influence of Subsurface Defects, Corros. Sci., 2011, 53, p 3914-3922

24. T. Ishitsuka and K. Nose, Solubility Study on Protective Oxide Films in Molten Chlorides Created by Refuse Incineration Environment, Mater. Corros., 2000, 51, p 177-181

25. A. Nishitasanwichka and S. Haruyama, Electrochemical Monitoring of the Corrosion of Ni, Fe, and Their Alloys in Molten Salts, Corrosion, 1986, 42, p 578-584

26. M.F. Ashby, Multi-objective Optimisation in Material Design and Selection, Acta Mater, 2000, 48, p 359-369

27. K.L. Edwards, Designing of Engineering Components for Optimal Materials and Manufacturing Process Utilization, Mater. Des., 2003, 24(5), p 355-366

28. M.F. Ashby, Y.J.M. Bréchet, D. Cebona, and L. Salvo, Selection Strategies for Materials and Processes, Mater. Des., 2004, 25, p 51-67

29. K.L. Edwards, Selecting Materials for Optimum Use in Engineering Components, Mater. Des., 2005, 26, p 469-473

30. K.L. Edwards, Materials Influence on Design: A Decade of Development, Mater. Des., 2011, 32, p 1073-1080

31. M.F. Ashby, Materials Selection in Mechanical Design, 3rd ed., Elsevier Butterworth-Heinemann, Oxford, 2005, p 8-160

32. CES Selector 2012 Software, Granta Design Ltd, Cambridge, 2012

33. M.F. Ashby, H. Shercliff, and D. Cebon, Materials: Engineering, Science, Processing and Design, 2nd ed., Butterworth Heinemann, Oxford, 2010, p 203-224

34. G.E. Dieter and H.A. Kuhn, Handbook of Workability and Process Design, ASM International, Materials Park, OH, 2003

35. J. Olsson, A Stainless Steel for Condenser Tubes, UNS S32654, Avesta Sheffield AB, S-774 80 Avesta, Sweden, 2010, p 27-89

36. G. Gemmel, Properties, Specifications and Experience of Welded Stainless Steel Pipes in the Grades UNS S31254, N08904, S32304, S31803 and S32750, M Sc. Metallurgy Manager Market Development Avesta Sandvik Tube AB 64421 Torshälla, Sweden, 2010

37. Special Metals Corporation, A Comparison of the Properties of Corrosion-Resistant Alloys and Titanium: An Aid for Specifying Cost Effective Materials for Demanding Applications, Special Metals Corporation, 3200 Riverside Dr. Huntington, WV 25705-1771 USA, 2005

38. S.A. McCoy, B.C. Puckett, and E.L. Hibner, High Performance AgeHardenable Nickel Alloys Solve Problems in Sour Oil and Gas Service, Special Metals Corporation, 3200 Riverside Dr. Huntington, WV 25705-1771 USA, 2002

39. J.R. Crum, L.E. Shoemaker, and S.D. Kiser, Special Alloys and Overmatching Welding Products Solve FGD Corrosion Problems, Special Metals Corporation, 3200 Riverside Dr. Huntington, WV 25705-1771 USA, 2010

40. B.A. Baker, G.D. Smith, and L.E. Shoemaker, Performance of Commercial Alloys in Simulated Waste Incineration Environments, Special Metals Corporation, 3200 Riverside Dr. Huntington, WV 25705-1771 USA, 2010

41. DIN 17175-79 standard: Seamless Steel Tubes for Elevated Temperatures, DIN Deutsches Institut für Normung e. V, 1979

42. C.X. Li and T. Bell, Corrosion Properties of Plasma Nitrided AISI, 410 Martensitic Stainless Steel in $3.5 \% \mathrm{NaCl}$ and $1 \% \mathrm{HCl}$ Aqueous Solutions, Corros. Sci., 2006, 48, p 2036-2049

43. M.J. Walter, Stainless Steel for Medical Applications, Adv. Mater. Process., 2006, 22, p 84-86

44. R.P. Anantatmula, S.J. Mayhan, and P.A. White, Microstructural Characterization of Advanced Ferrous Alloys Exposed to Liquid Sodium, Annual Technical Meeting of the International Metallographic Society, Houston, TX, USA, 1977

45. N. Wanderka, V. Naundorf, J. Banhart, D. Mukherji, D. Del Genovesse, and J. Rodsier, Microstructural Characterization of Inconel 706 alloy, Surf. Interface Anal., 2004, 36, p 546-551

46. D.J. Coates, B. Mortimer, and A. Hendry, The Oxidation and Corrosion Resistance of Nitrided Iron Alloys, Corros. Sci., 1982, 22, p 951-972 